\title{
BAZSA GYÖRGY
}

professor emeritus

Debreceni Egyetem, Természettudományi és Technológiai Kar

ORCID Nr. 0000-0002-5768-7064

bazsa@unideb.hu

\section{„AZ EGYETEM LÉTESÍTÉSÉNEK LEGJOBB MUNKÁSA” EGY GYÁSZJELENTÉS MARGÓJÁRA}

\begin{abstract}
A debreceni Egyetem létesitésében meghatározó szerepet vállalt és vitt gróf Degenfeld József, egyrészt mint Debrecen fóispánja, másrészt mint a Tiszántúli Református Egyházkerület fógondnoka. Az állami egyetem ezt még életében szimbolikusan is demonstrálta azzal, hogy fölvételi épületének felavatásán - a királyi pár jelenlétében - egyházi tisztségviselöként ö mondta az ünnepi beszédet. Elhunytakor pedig külön gyászjelentést adott ki, amiben öt „, az egyetem létesitésének legjobb munkása” elismeréssel illette.
\end{abstract}

Kulcsszavak: Degenfeld József, az egyetem létesítése, külön gyászjelentés, „legjobb munkás”

"THE BEST WORKER OF THE UNIVERSITY'S ESTABLISHMENT" - IN THE MARGIN OF AN OBITUARY. Count József Degenfeld took on a decisive role in the establishment of the University of Debrecen on the one hand as the major of Debrecen and on the other hand as the chief guardian of the Trans-Tisza Reformed Diocese. The state university has already expressed its honour symbolically in his life by providing the solemn address as a church official at the inauguration of the reception building in the presence of the royal couple. When he died it issued a special obituary acknowledging him as "the best worker of the university's establishment".

Keywords: József Degenfeld, establishment of the university, special obituary, "best worker"

Gróf Degenfeld Schomberg József elhunytakor (1927. július 12.) a kor szokásainak megfelelő formában a család gyászjelentést adott ki, felsorolva abban egyrészt a gyászoló családtagokat, másrészt az elhunyt közéleti tevékenységét és kitüntetéseit. ${ }^{1}$ Az egyházkerületi fögondnok esetében az is természetes, hogy a Tiszántúli Református Egyházkerület és Debreceni Kollégiuma külön gyászjelentést adott közre. ${ }^{2}$ Érdemeit és eredmé-

\footnotetext{
${ }^{1}$ https://library.hungaricana.hu/hu/view/Gyaszjelentesek_DebreceniRefKollNagykonyvtara_DEBDZ/?pg= 49\&layout=s. Hozzáférés: 2021. 11. 15.

${ }^{2}$ Uo.
}

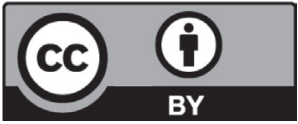

Beérkezett: 2021. 08. 15.

Közlésre elfogadva: 2021. 10. 15.

Copyright GERUNDIUM 
nyeit elismerendő a Kollégium dísztermében ravatalozták fel és a Nagytemplomban tartották a gyászszertartást, amin helyi és országos notabilitások körében Horthy Miklós kormányzó is részt vett. ${ }^{3}$

Ezek mellett az egyetem külön gyászjelentést jelentetett meg. Formálisan nem lett volna kötelessége, hiszen a díszdoktori cím nem olyan súlyú kapcsolat, aminek okán saját gyászjelentést kell kiadni. ${ }^{4}$

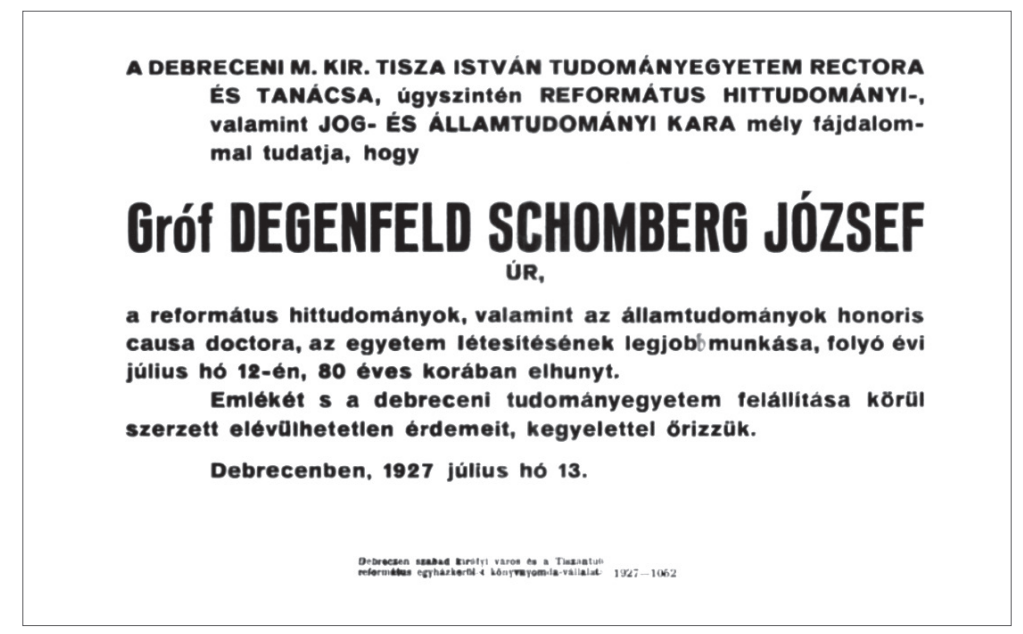

Ennek szövegéből viszont pontosan látszik mégis, miért tette ezt: „[...] a debreceni tudományegyetem felállítása körü̈l szerzett elévülhetetlen érdemeiért [...]", amik alapján öt „[...] az egyetem létesitésének legjobb munkása” elismeréssel illeti.

\section{Ki volt gróf Degenfeld Schomberg József?}

1883 és 1901 között Debrecen város és Hajdú vármegye főispánja, 1896-tól 1926-ig, az egyetemi fóépület alapkőletételéig a Tiszántúli Református Egyházkerület fögondnoka. Mindkettő széles hatáskört, nagy felelősséget jelentő és egyúttal nagy lehetőséget nyújtó tisztség volt, $s$ ő ezeket ennek megfelelően is látta el.

Magánéletéről annyit tudunk, hogy 1847. december 21-én Kolozsváron született, a 13. században Svájcból indult és kalandos utakon országrészünk és Erdély sok helyén letelepedett nemesi család sokadik nemzedékének sarjaként. Budapesten jogot végzett és doktori címet szerzett. 1870. május 17 -én vette feleségül Losoncon a helyi illetékességü Szilassy Irmát (1849, Losonc-1892, Debrecen). Házasságukból három gyermek született: Ottó (1872, Szirák), Anna (1875, Budapest) és Augusta (1876, Wasserburg

${ }_{3}^{3}$ Ravasz László püspök beszéde Degenfeld József ravatalánál. https://www.lelkesz.com/predikacio/51300302. Hozzáférés: 2021. 11. 15.

${ }^{4}$ Gyászjelentés. 


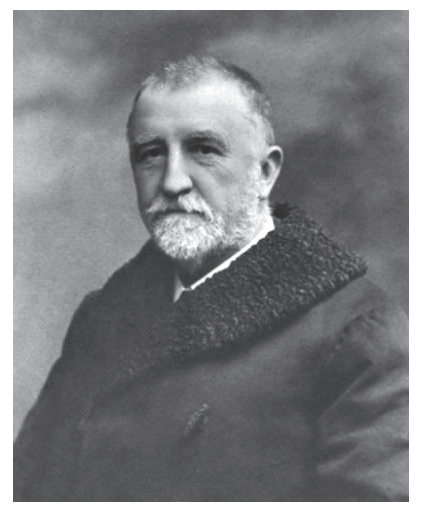

am Inn). A téglási Degenfeld-Schomburg Kastély honlapján olvasható családfa szerint utódaik ma is nagy számban élnek, de már szinte mindannyian külföldön. ${ }^{5}$ (Magyarországra, például a tarcali kastélyba a család más ágának tagjai jöttek vissza.)

A Kollégiumban 1927. október 26-án a tiszteletére tartott emlékünnepélyen, ahol az egyetem Tanácsa is teljes létszámban megjelent, (Szentpéteri) Kun Béla profeszszor így foglalja össze Degenfeld Józsefnek az egyház, a Kollégium, a város és az egyetem érdekében végzett tevékenységét: ${ }^{6}$

„[...] új rend az egyházkerület pénzügyeiben, kapcsolatban messze jövőre átgondolt nagyszerủ koncepciókkal, a kollégium egész kormányzatának újjászervezése, a vagyonkezelés tervszerűbb ellenőrzésével; a kollégium minden irányban hatalmas fejlödése, a tanárok anyagi helyzetének jelentékeny javításával, a felső tagozatok teljes kiépítésével; a gyönyörủ új gimnázium, új konviktus, a főiskolai ifjak számára való modern internátus; a református theológiai fakultással felállított debreceni tudományegyetem, melynek létesülhetéséből az oroszlánrészt nem lehet tőle elvitatni; a kollégium elvesztett felső tagozatai helyébe állított lelkészés tanárképző intézet: hangosan beszélnek alkotó erejéről."

Ez az el nem vitatható oroszlánrész tükröződik az egyetem saját gyászjelentésében. A debreceni egyetem történetéről tudjuk, hogy Török József, a Kollégium profeszszora 1870. május 5-én fogalmazta meg elöször: „A debreceni föiskolának egyetemmé kell alakulnia. Ez a legvirágzóbb fóiskola, Debrecen földrajzi helyzete is alkalmassá teszi erre. " A folyamat nehezen indult és elég lassan haladt, mígnem az 1912. évi XXXVI. tc. kimondta a Debreczeni Magyar Királyi Tudományegyetem (és a pozsonyi) létrehozását. A folyamat részleteit itt nem tárgyaljuk, elég, ha az egyetem centenáriumi kiadványára utalunk. ${ }^{8}$ Onnan idézünk: „Mivel az egyházkerületi ügyek vezetése már évek óta a fögondnok kezében volt, ez a felhatalmazás valójában Degenfeldnek, a debreceni egyetem ügye legerösebb mozgatójának adatott." Degenfeld meghatározó szerepét az egyetemmé válásban jól dokumentálja három fontos esemény:

${ }^{5}$ http://www.degenfeldkastely.com/a-kastelyrol/degenfeld-csaladtortenet. Hozzáférés: 2021. 11. 15.

${ }^{6}$ A példaadó vezér. Emlékbeszéd, melyet gróf Degenfeld Schomberg József egyházkerületi fögondnok emlékezetére a Tiszántúli Református Egyházkerület 1927 október 26-i közgyülése alkalmával tartott gyászünnepélyen mondott dr. Szentpéteri Kun Béla egyházkerületi világi tanácsbiró. ([Debrecen], Debrecen szabad királyi város és a Tiszántúli Ref. Egyházkerület Könyvnyomda vállalata, 1927).

7 Vö. Fekete Károly rektor beszéde. https://www.drhe.hu/hu/debreceni-reformatus-hittudomanyi-egyetemtanevnyito-unnepsege. Hozzáférés: 2021. 11. 15.

8 Mudrák József, „Egyetemalapítási tervek és a Debreceni Tudományegyetem megalakulása”, in A Debreceni Egyetem története 1912-2012, szerk. Orosz István és ifj. BARTA János (Debrecen: Debreceni Egyetemi Kiadó, 2012), 41-56. 
1891-ben az Országos Református Zsinaton Kiss Áron tiszántúli püspök, Degenfeld József tiszántúli fógondnok és Tóth Sámuel debreceni teológiai professzor - az egyetemmé válás érdekében - kezdeményezték (a teológiai és jogi mellé) egy bölcsészeti fakultás szervezését a Református Kollégiumban.

A Kollégium és a létesítendő tudományegyetem közötti viszonyról a kormány és az egyházkerületi elnökség között megállapodások jöttek létre, amelyeket a vallás- és közoktatásügyi miniszter 1911. november 4-i, illetve november 13-i gróf Degenfeld József egyházkerületi fögondnokhoz intézett leiratában foglalt össze. Ezeket tárgyalta meg - s hagyta jóvá egyhangúlag - a Tiszántúli Református Egyházkerület 1911. november 22-24-i közgyűlése. Ott a fögondnok így fogalmazott: „A mi föiskolánk egy nagy és gyökeres átalakulás küszöbén áll. Kétségtelen, hogy igen nagy felelösséget vállalnak magukra azok, kik ezen átalakulás eszközlésében részt vesznek. Tudom, érzem, hogy ezen felelösségnek igen nagy része az én vállamon van." "

1918. október 23-án avatták fel az orvoskari felvételi épületet. IV. Károly királyt és feleségét, Zita királynét az egyetemi tanács élén Zichy János vallás- és közoktatásügyi miniszter, valamint Degenfeld József egyházkerületi fógondnok fogadta. Itt - Zichy János miniszter köszöntője után - Degenfeld József református főgondnok mondta az ünnepi beszédet:
„[...] úgy az egyházkerület nagy többsége, valamint Debrecen városa mely föis- kolánknak mindenkor kegyes patrónusa volt, s a debreceni református egyház is lelkesen támogatta a mozgalmat, belátva, hogy ily kulturális intézmény, mint az egyetem, mily rendkívüli, minden irányú előnyt képez városunkra, egyszersmind a hazai reformátusságra nézve is, melynek Debrecen a központja." ${ }^{10}$ A fógond- nok szavaira a király egyetértően válaszolt. ${ }^{11}$

Szentpéteri Kun Béla említett méltatása végén reményét fejezte ki: „Majd meg fogják irni gróf Degenfeld József élettörténetét." De ez a remény azóta sem teljesült. Pedig indokolt lenne - még ma is.

A gyászjelentés felidézése felveti a sírhely, a síremlék kérdését is. 1932-ben, az új, ma is működő Köztemető megnyitásakor a Kossuth utcai temetőt (is) lezárták. Onnan idővel számos sírt/síremléket áthelyeztek a Köztemetőbe vagy máshová. Degenfeld József és felesége síremléke ma a Debrecen-Széchenyi kerti Református Egyházközség templomának kertjében (István király tér 2.) áll több mint tíz, az egyház történetében fontos szereppel bíró személyével együtt. ${ }^{12}$ Degenfeld Józsefné fiatalon, 43 évesen halt

\footnotetext{
${ }^{9}$ Kun Béla, „A debreczeni m. kir. tudományegyetem létesítésének története”, A Debreczeni m. kir. Tudományegyetem almanachja az 1914-15-ik tanévre, 3-51.

${ }^{10}$ Béres Zsuzsa, „A Debreceni Magyar Királyi Tudományegyetem [foépületének] avatása - 1918. október 23.” Gerundium - Egyetemtörténeti Közlemények 10, 2. sz. (2019): 121.

${ }^{11} \mathrm{Az}$ ünnepségen gróf Tisza István - nem tudni miért - nem vett részt, aznap Budapesten volt.

${ }^{12}$ Köszönöm Degenfeld-Lindner Mária segítségét a síremlékek helyének megtalálásában.
} 
meg. Férjét 36 évvel később minden bizonnyal ugyanabba a sírba temették, de külön sírkövet, érthetően nagyon hasonlót kellett készíttetni számára. Ezeket mutatják mai helyükön a képek.
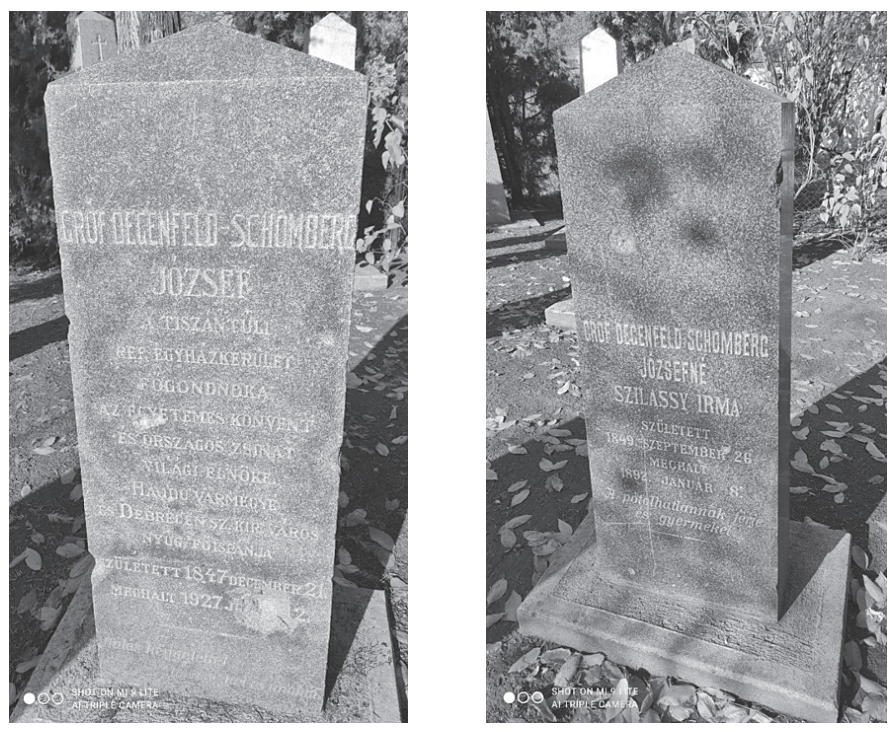

Degenfeld Józsefnek még egy emléke van városunkban: a Református Kollégium belső árkádsorában 1938-ban elhelyezett relief, Nagy Sándor János alkotása. Felirata: „DEGENFELD JÓZSEF gróf - 1896-1927 egyházker. fögondnokunk, az egyetemmé alakulás egyik irányitója, egyetemünk H.D.TH és R.PO doctora." ${ }^{13}$ A Kollégium Múzeuma örzi Degenfeld $22 \times 16 \mathrm{~cm}$-es korábban megjelenített arcképét. ${ }^{14}$

Ugyanakkor nem méltó emlékéhez, hogy a városközpontban lévő, róla elnevezett Degenfeld tér nevét 1948-ban a Tóthfalusi térre változtatták, és a rendszerváltáskor, 1990-ben sem kapta vissza nevét: ma Dósa nádor a tér névadója.

A fentiek azt mondják jelenünknek: Debrecen városának és a Debreceni Egyetemnek gróf Degenfeld Józsefhez, az „egyetem létesitésnek legjobb munkásá”-hoz illő kötelessége lenne máig ható tevékenységének, emlékének elevenen tartása és méltó megörökítése a közvélemény, ma és az utókor számára.

${ }^{13} \mathrm{http}: / /$ www.dbvk.hu/szoborpark/index.php?do=search\&mode=result\&tipus=mezo_kereses_m_ cim\&term=Degenfeld. Hozzáférés: 2021. 11. 15.

${ }_{14}$ Magyar Nemzeti Digitális Archívum. https://mandadb.hu/tetel/32394/Degenfeld_Jozsef_grof_arckepe. Hozzáférés: 2021. 11. 15. Lelőhely: DRK Múzeum C.1968.125. 